\title{
Three new Navicula (Bacillariophyta) species from an oligotrophic, deep lake, China
}

\author{
Yanling Li $^{1 *}$, Mengna LiaO ${ }^{2} \&$ Ditmar Metzeltin ${ }^{3}$
}

\author{
IInstitute for Ecological Research and Pollution Control of Plateau Lakes, School of Ecology and Environmental \\ Science, Yunnan University, 650504, China.*Corresponding authore-mail:yanlingli@ynu.edu.cn, ylli@ \\ niglas.ac.cn \\ ${ }^{2}$ College of Chemistry and Life Sciences, Zhejiang Normal University, Jinhua 321004, P. R. China \\ ${ }^{3}$ Am Stegskreuz 3b, D-65719 Hofheim, Germany
}

\begin{abstract}
Three new freshwater diatoms are described from China's Yunnan Plateau region in sediments from Lake Fuxian. Navicula australasiatica nov. sp., Navicula perangustissima nov. spec., and Navicula turriformis nov. spec. were identified from light and scanning electron micrographs. All new species are sufficiently different from other similar species based on valve outline, shape of the axial and center areas, and stria density. These three new species are all observed in surficial sediment from Lake Fuxian and compared to morphologically similar species from the genus Navicula.
\end{abstract}

Key words: ancient lake, China, diatom, Lake Fuxian, new species, Navicula

\section{INTRODUCTION}

Fuxian Lake is an oligotrophic, deep lake, and the most important fresh-water resource of Yunan Province in China accounting for around two-thirds of the total fresh-water storage in the Yunnan Plateau (WANG \& Dou 1998). Lake Fuxian fits some aspects of the ancient lake model as there are several endemic fishes and oligochaetes, and, among the diatoms, endemic species (SkUJA 1937; Li et al. 2010a, b; Gong \& Li 2011). Lake Fuxian was formed by faulting in the late Pliocene (3.0-4.0 Ma), is one of the characteristic tectonic lakes of the Yunnan-Guizhou Plateau. Ancient lake systems harbor some of the highest diversity of any freshwater ecosystems and are characterized by endemism and groups of related species often referred to as species flocks (Brooks 1950; EdLund \& Soninkhishig 2009). Lake Fuxian have also unique fauna (mainly fish, Crustacea and Oligochaeta, including 14 endemic diatom species) and flora (including 7 endemic diatom species) (YANG \& Chen 1995; SKet 2000; CuI \& WANG 2005). Zhu \& CHEN (1994) reported 18 and 49 taxa from Lake Fuxian in 1957 and 1989, respectively. In more recent studies on Lake Fuxian, new diatoms have been reported, including the description of three new Sellaphora species (Sellaphora fuxianensis $\mathrm{Li}$, Sellaphora yunnanensis $\mathrm{Li}$ et Metzeltin, Sellaphora sinensis Li et Metzeltin) (LI et al. 2010a, b), one new Cymbella species (Cymbella fuxianensis Li et Gong) (Gong \& Li 2011), and three new Navicula species (Navicula craticuloides Li et Metzeltin, Navicula gongii Metzeltin et Li and Navicula yunnanensis Li et Metzeltin) (GoNG et al. 2015). In this paper, we continue to document the diatom diversity of the lake and report three new Navicula species based on analyses of surficial sediments using light and scanning electron microscopy.

\section{Materials And Methods}

One sample $\left(24^{\circ} 24.870^{\prime} \mathrm{N}, 102^{\circ} 50.590^{\prime} \mathrm{E}\right)$ was collected from surficial sediment $(0.5 \mathrm{~cm})$ of Lake Fuxian using a Kajak gravity corer in 2005. Diatom samples were treated using $10 \% \mathrm{HCl}$ to dissolve calcium carbonate and $30 \% \mathrm{H}_{2} \mathrm{O}_{2}$ to oxidize the organic matter (BATTARBEE 1986). All samples and slides are deposited in the Herbarium of Nanjing Institute of Geography and Limnology. Diatoms were identified under oil immersion at $1000 \times$ magnification with an Olympus microscope (BX51DIC). Cleaned material for scanning electron microscope (SEM) analysis was air-dried onto cover glasses, mounted onto stubs, and coated with $20 \mathrm{~nm}$ of Au. Samples were examined and photographed using a Leo 1530 . 


\section{RESULTS}

Navicula australasiatica Li et Metzeltin, sp. nov. (Figs 1-8)

Description

Light microscopy (Figs 1-5): Valves linear-lanceolate to linear, ends wedge-shaped. Length $86-95 \mu \mathrm{m}$, breadth 12-13 $\mu \mathrm{m}$. Raphe filiform with central ends clearly deflected to the primary side of the valve with small central pores lying in the expanded part of the asymmetrical central nodule. Axial area very narrow, straight. Central area transapically expanded rectangular, large, confined by $3-5$ hardly radiate, shortened striae. Other striae distinctly radiate becoming abruptly subparallel at the conspicuous Voigt fault, finally convergent near the ends, consistently 7-7.5 in $10 \mu \mathrm{m}$. Lineolae appearing coarser, clearly wider spaced, 24-25 in $10 \mu \mathrm{m}$.

Scanning electron microscopy (Figs 6-8): In SEM external view, raphe distinctly curved and central pores deflected to the primary side. The central pores curved like crochet-hooks (Figs 6-8).

Holotype: HANU! Individual in slide YUNFX2005326 (Harbin Normal University Heilongjiang Harbin ). Isotype: YNU! Individual in slide 46109 (School of Ecology and Environmental Science, Yunnan University).

Type locality: Surficial sediments of Lake Fuxian $\left(24^{\circ} 24.870^{\prime} \mathrm{N}, 102^{\circ} 50.590^{\prime} \mathrm{E}\right)$

Ecology and confirmed distribution: So far this species only observed in surficial sediments of Lake Fuxian. In this site, diatom assemblages were dominated by Cyclotella krammeri Häkansson, Stephanodiscus hantzschii Grunow, Fragilaria crotonensis Kitton, Cyclotella rhomboideo-elliptica Skuja, Achnanthes Bory et St.-Vincent, Amphora Ehrenber, Aulacoseira granulata (Ehrenberg) Simonsen, and Stephanodiscus minutulus (Kützing) Cleve et Möller.
Navicula perangustissima Li et Metzeltin, sp. nov. (Figs 9-24)

Description

Light microscopy (Figs 9-18): Valves narrowly lanceolate with rather acutely rounded apices being occasionally gradually protracted, particularly in longer specimens. Length 34-61 $\mu \mathrm{m}$, breadth 6-7 $\mu \mathrm{m}$. Ratio length/breadth 5.2-9.0. Raphe filiform to weakly lateral with narrowly spaced small central pores. Axial area narrow to very narrow, linear, not or very little widened near the small central area which varies in shape due to irregularly shortened few stria pairs. Transapical striae radiate throughout, 14-17 in $10 \mu \mathrm{m}$. Lineolae coarse, 22-24 in $10 \mu \mathrm{m}$.

Scanning electron microscopy (Figs 19-24): In SEM external view, raphe with central pores curved like the head of a crosier. The terminal raphe fissures arising from the terminal pores run almost straight to the valve mantle with forming a clear curve to the secondary side. Satellite pore difficult to discern. Foramina lying in continuous depressions between distinct apical ribs masking the apical costae. The inner surface of the valve reveals almost square areolae with hardly any suggestion of sunken alveoli (Figs 19-21).

In SEM internal view, the raphe sternum with central nodule and additional rib are likewise comparatively narrow (Figs 22-24).

Holotype: HANU! Individual in slide YUNFX2005327 (Harbin Normal University Heilongjiang Harbin). Isotype: YNU! Individual in slide 46110 (School of Ecology and Environmental Science, Yunnan University).

Type locality: surficial sediments of Lake Fuxian $\left(24^{\circ} 24.870^{\prime} \mathrm{N}, 102^{\circ} 50.590^{\prime} \mathrm{E}\right)$.

Etymology: the specific epithet refers to the close relation with $N$. angustissima.

Ecology and confirmed distribution: So far this species only observed in surficial sediments of Lake Fuxian.

Table 1. Morphological characteristics of $N$. australasiatica sp. nov. and Navicula species sharing similar morphological features.

\begin{tabular}{lllll}
\hline Species /Feature & N. australasiatica & $\begin{array}{l}\text { N. vuridula } \\
\text { (Kützing) } \\
\text { Ehrenberg }\end{array}$ & $\begin{array}{l}\text { N. viridula } \\
\text { var. linearis Hustedt }\end{array}$ & $\begin{array}{l}\text { N. viridulacalcis Lange- } \\
\text { Bertalot in Rumrich }\end{array}$ \\
\hline Reference & this study & $\begin{array}{l}\text { LANGE-BERTALOT } \\
2001\end{array}$ & MAIDANA 1996 & LANGE-BERTALOT 2001 \\
Valve length, $\mu \mathrm{m}$ & $86-95$ & $40-100$ & $55-65$ & $30-65$ \\
Valve width, $\mu \mathrm{m}$ & $12-13$ & $10-15$ & $6-8$ & $8-12$ \\
Lineolae in $10 \mu \mathrm{m}$ & $24-25$ & 24 & $28-29$ & $21-25$ \\
Stria in $10 \mu \mathrm{m}$ & $7-7.5$ & $8-11$ & $8-12$ & $8-11$ \\
Valve shape & $\begin{array}{l}\text { Linear-lanceolate } \\
\text { to linear }\end{array}$ & $\begin{array}{l}\text { Linearto } \\
\text { linear-lanceolate }\end{array}$ & Linear-lanceolate & Linear \\
End shape & wedge-shaped & $\begin{array}{l}\text { Obtusely rounded, } \\
\text { strongly protacted }\end{array}$ & Apices sub-rostrate & Abruptly wedge-shaped \\
\hline
\end{tabular}


Table 2. Morphological characteristics of $N$. perangustissima sp. nov. and Navicula species sharing similar morphological features.

\begin{tabular}{lllll}
\hline Species /Feature & N. perangustissima & $\begin{array}{l}\text { N. angustissima } \\
\text { Hustedt }\end{array}$ & N. kristicii Levkov & $\begin{array}{l}\text { N. trophicathrix } \\
\text { Lange-Bertalot }\end{array}$ \\
\hline Reference & this study & HusteDT 1934 & LEVKOv et al. 2007 & $\begin{array}{l}\text { LANGE-BERTALOT \& } \\
\text { METZELTIN 1996 }\end{array}$ \\
Valve length, $\mu \mathrm{m}$ & $34-61$ & $50-75$ & $42-61$ & $25-50$ \\
Valve width, $\mu \mathrm{m}$ & $6-7$ & $11-13$ & $7-9.5$ & $7.5-10$ \\
Ratio length/breadth & $5.2-9.0$ & $5.9-6.3$ & $6-6.2$ & $3.3-5.3$ \\
Stria in $10 \mu \mathrm{m}$ & $14-17$ & $7-10$ & $12-14$ & $11-13$ \\
Valve shape & Narrowly lanceolate & Lanceolate & Narrowly lanceolate & $\begin{array}{l}\text { Lanceolate to } \\
\text { rhombic-lanceolate }\end{array}$ \\
End shape & Rounded, protracted & $\begin{array}{l}\text { Abruptly } \\
\text { wedge-shaped }\end{array}$ & $\begin{array}{l}\text { Subrostrated ends, } \\
\text { protracted }\end{array}$ & $\begin{array}{l}\text { Narrowed to wedge- } \\
\text { shaped, acutely rounded }\end{array}$ \\
\hline
\end{tabular}

Navicula turriformis Li et Metzeltin, sp. nov. (Figs 25-40)

\section{Description}

Light microscopy (Figs 25-34): Valves generally elliptical to elliptical-lanceolate; ends becoming broadly cuneate with more or less distinctly pointed apices. The ends shape resembles with the apex of Gomphonema turris. Length 41-66 $\mu \mathrm{m}$, breadth $15.5-19.5 \mu \mathrm{m}$. Length-to-breadth ratio 3.0-3.8. Raphe filiform to slightly lateral with tear drop-like central pores appearing very weakly deflected to the primary side of the valve; terminal fissures shortly hooked just as in $N$. turris. Axial area narrow-linear, not or slightly expanded proximally. Central area distinctly much more expanded transapically, bow-tie-shaped. Striae moderately radiate throughout, two or three pairs irregularly shortened proximally, 6-7.5 in $10 \mu \mathrm{m}$. Voigt fault to discern more or less easily. Lineolae comparatively coarse, 19-21 in $10 \mu \mathrm{m}$.

Scanning electron microscopy (Figs 35-40): In SEM external view (Figs 35-37), almost straight central raphe ends with simple drop-like expanded central pores. The sternum neither depressed not conspicuously expanded at the central nodule. The terminal raphe fissures arising from the terminal pores run almost straight to the valve mantle with forming a curve and turning to opposite sides at both poles. In SEM internal view, the raphe sternum with central nodule and additional rib are likewise comparatively narrow. Raphe terminates at the apices in a curved helictoglossa (Figs 38-40).

Holotype: HANU! Individual in slide YUNFX2005328 (Harbin Normal University Heilongjiang Harbin ). Isotype: YNU! Individual in slide 46111 (School of Ecology and Environmental Science, Yunnan University).

Type locality: surficial sediments of Lake Fuxian $\left(24^{\circ} 24.870^{\prime} \mathrm{N}, 102^{\circ} 50.590^{\prime} \mathrm{E}\right)$.

Etymology: the specific epithet refers to the close relation with $N$. turris.
Ecology and confirmed distribution: So far this species only observed in surficial sediments of Lake Fuxian.

\section{Discussion}

In Lake Fuxian, we collected 22 samples in different sites, but the new species were found at only one site, which may be related to the microenvironment of the site where water depth was $19 \mathrm{~m}$, while water depths of other sites were more than $36 \mathrm{~m}$. Increased eutrophication in Lake Fuxian is of concern, especially for its endemic species, which are often the most vulnerable to changing environmental conditions (EDLUND \& JAHN 2001).

The characters and habitat of $N$. australasiatica resemble Navicula viridula var. linearis Hustedt from Lake Toba in Sumatra (MaIDANA 1996). The main distinguishing feature is the significantly lower areola density of this species (24-25 in $10 \mu \mathrm{m})$ and wedge-shaped ends, while that of $N$. viridula var. linearis is $28-29$ in $10 \mu \mathrm{m}$ and abruptly wedge-shaped. Without doubt, our species belong to the subgen. Alinea in which the central pores of the raphe are clearly deflected to the primary side of the valve (LANGE-BERTALOT 2001). It is also distinguished from Navicula viridulacalcis Lange-Bertalot in Rumrich (LANGE-Bertalot 2001) by length, breadth, stria density and shape. Length, breadth, stria density of $N$. viridulacalcis are 30-65 $\mu \mathrm{m}, 8-12 \mu \mathrm{m}, 21-25 / 10 \mu \mathrm{m}$, and its ends are abruptly wedge-shaped, respectively (LANGE-BERTALOT 2001). The outline shape of this species is rare, as it is in all the similar species (Table 1).

A few species of Navicula s. str. share this type of structural pattern which includes a more or less narrow-lanceolate valve shape, radiate striae throughout with coarse, apically short lineolae from the centre, the 


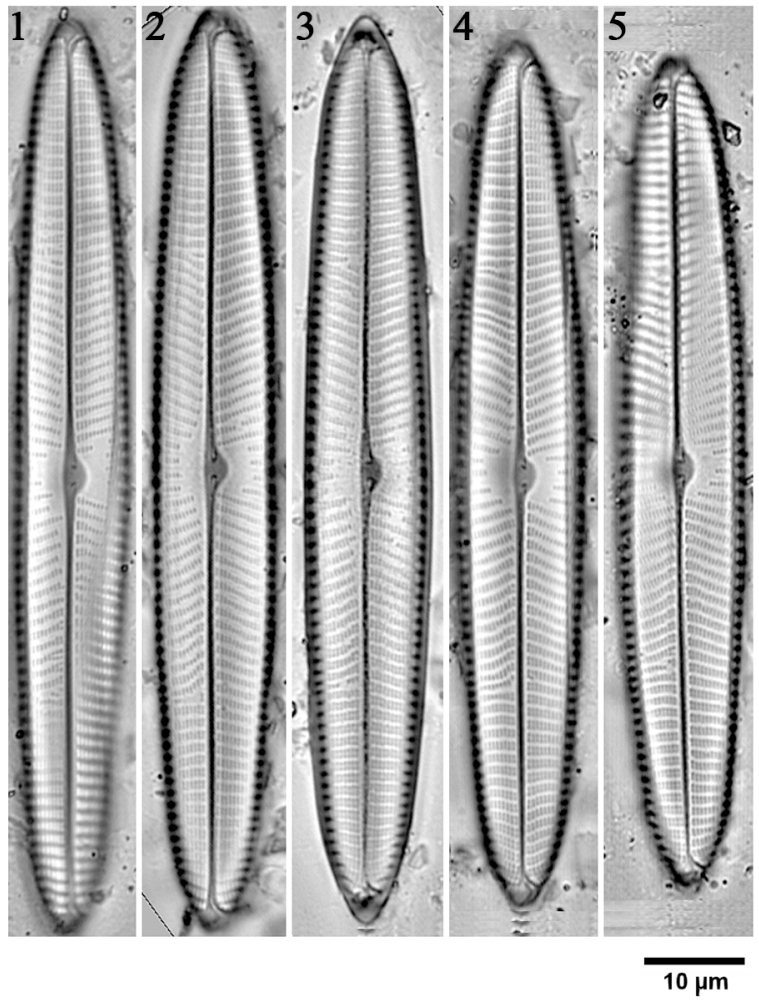

Figs 1-5. Navicula australasiatica, light microscopy (LM), valve views showing size diminution series. Fig. 1 is the holotype. Scale bar $10 \mu \mathrm{m}$.
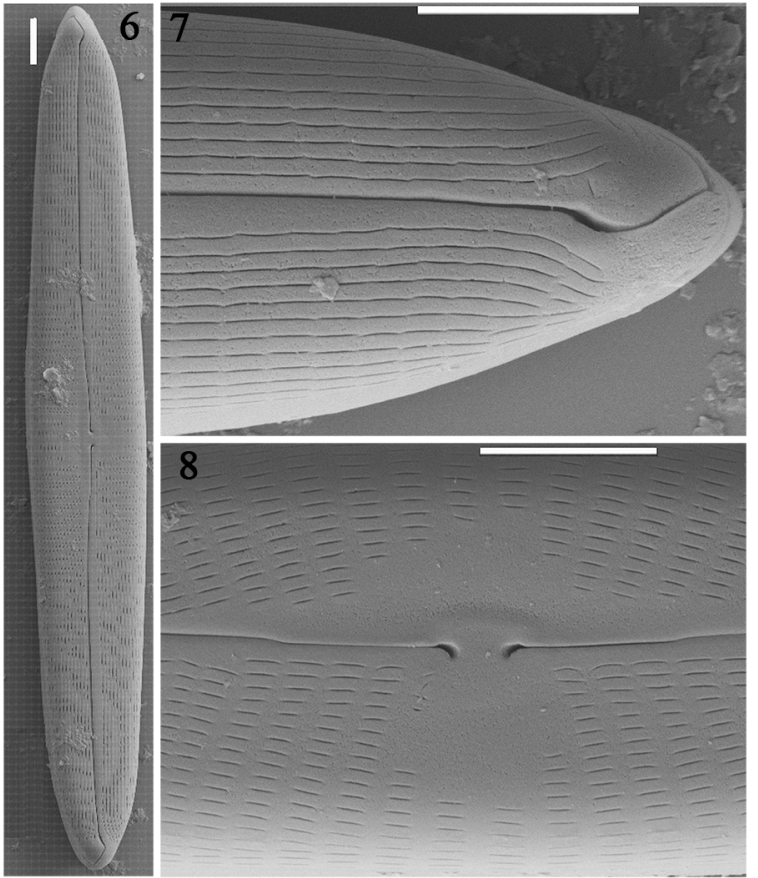

Figs 6-8. Navicula australasiatica, SEM, external views: (6) entire valve view; (7) view of the end with prolongation of the raphe slit from a terminal pore to the valve mantle with a clear curve to the secondary side; (8) central portion of the valve showing distinctly curved like crochet-hooks. Scale bar $10 \mu \mathrm{m}$.

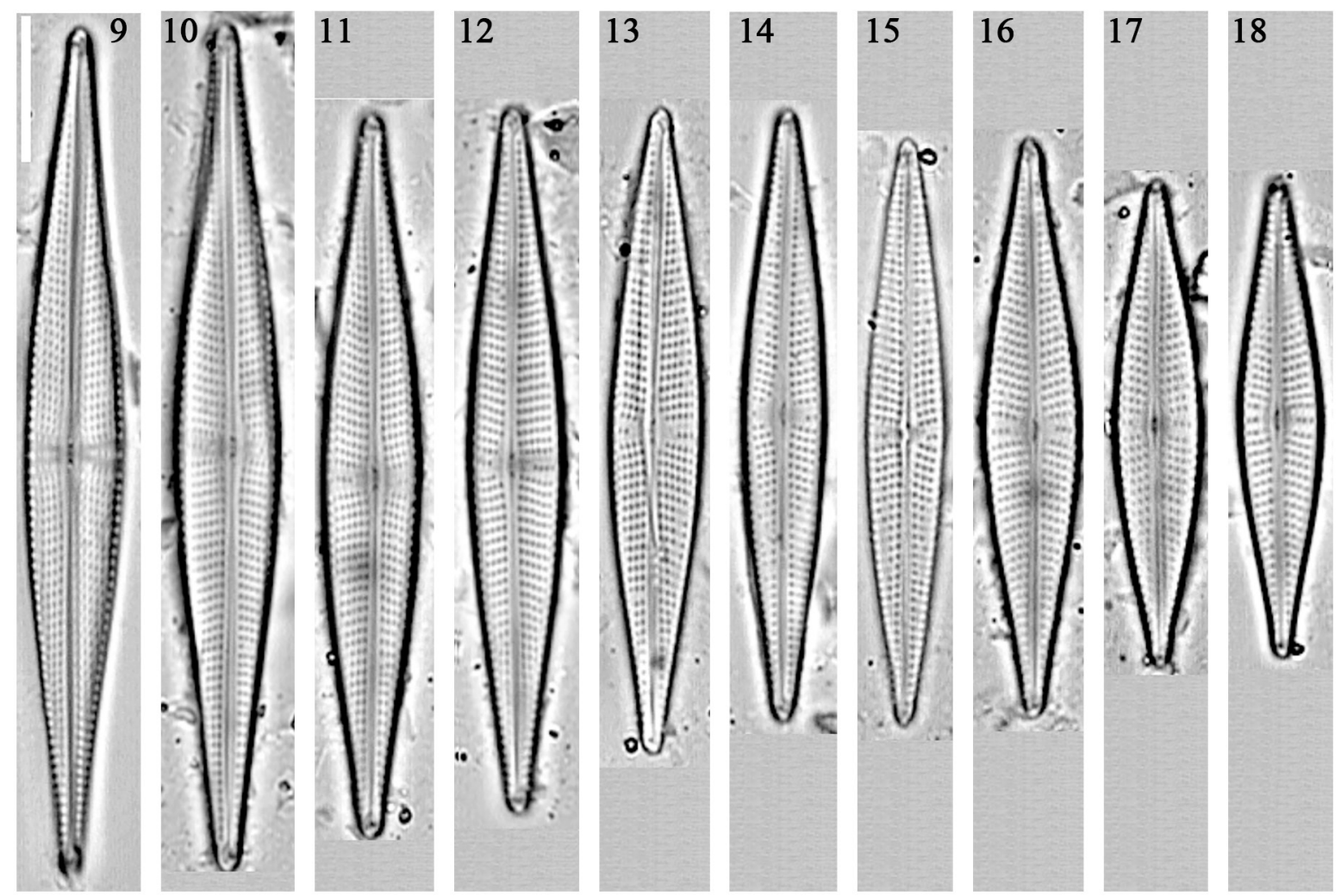

Figs 9-18. Navicula perangustissima, LM, valve views showing reduction. Fig. 9 is the holotype. 


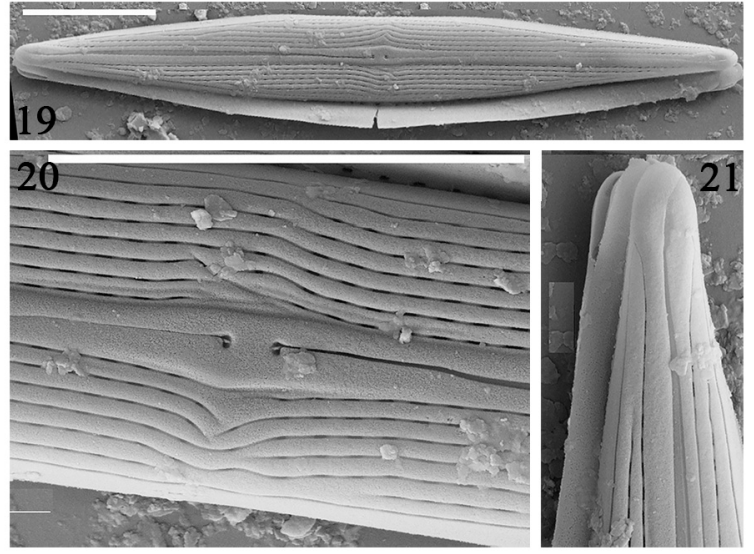

Figs 19-21. Navicula perangustissima. SEM, external views: (19) entire valve view; (20) central portion of the valve with central pores curved like the head of a crosier, there are longitudinal grooves along the valve, aligned with the lineolae; (21) view of the end showing distal raphe end deflected onto the valve mantle. Scale bar $10 \mu \mathrm{m}$.

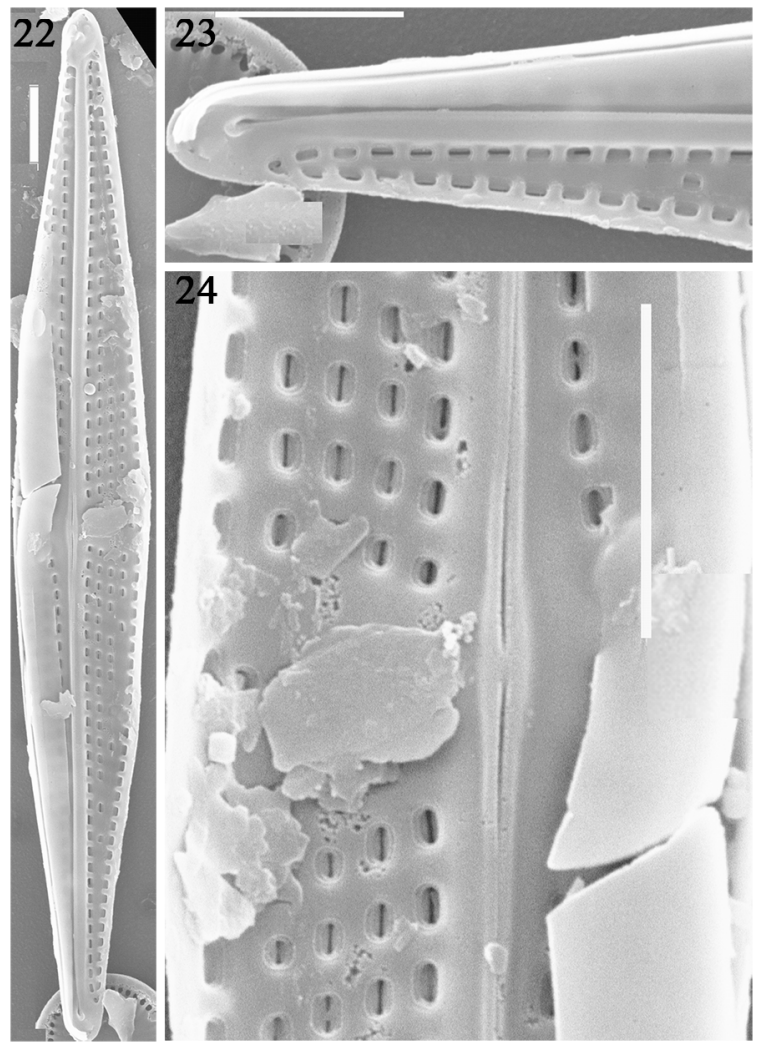

Figs 22-24. Navicula perangustissima, SEM, internal views: (22) internal valve view with central nodule, raphe slit and helictoglossae; (23) helictoglossa slightly offset from raphe terminates; (24) central nodule with scarcely expanded and inclined to the secondary valve side. Scale bar $3 \mu \mathrm{m}$.

median striae are wider spaced towards ends, and central pores with "satellite pores" visible in SEM. Navicula trophicathrix is a prominent example from Europe, and possesses the same combination of morphologic characters. N. trophicathrix Lange-Bertalot in LANGE-BERTALOT \& Metzeltin (1996) differs by a length-to-breadth ratio
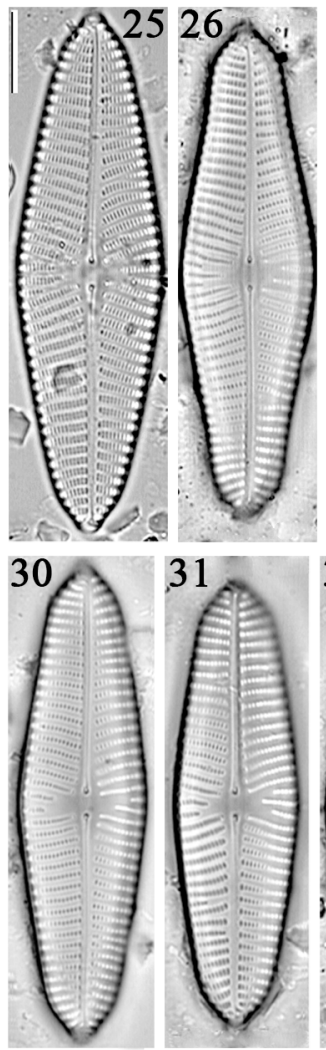

32
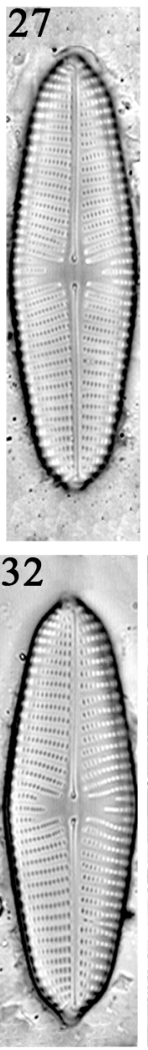

28

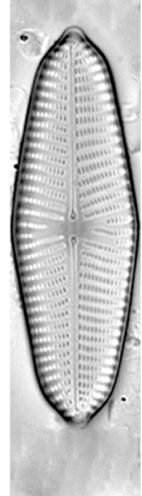

29

33

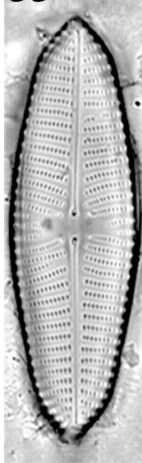

34

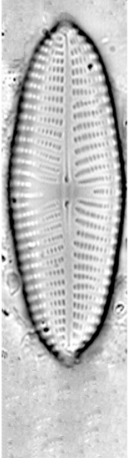

Figs 25-34. Navicula turriformis, LM, valve views showing size diminution series for the species. Fig. 25 is the holotype. Scale bar $10 \mu \mathrm{m}$.

of 3.3-5.3. N. perangustissima is distinguished from Navicula angustissima Hustedt by breadth and striae in $10 \mu \mathrm{m}$ ( N. angustissima breadth 11-13 $\mu \mathrm{m}$, transapical striae $7-10$ in $10 \mu \mathrm{m})$. The outline shape of this species is rare, as it is in all the similar species (Table 2).

Despite $N$. turriformis have resemblance of dimensions of valve outlines, and most of the other morphological characters conspecificity with $N$. turris. They are very unlikely considering the different central area and lineola densities. The central area and stria densities of $N$. turris are slightly greater, 25-28 in $10 \mu \mathrm{m}$. Remarkable in a wider context is that LEVKov et al. (2007) found $N$. turris in Lake Ohrid whereas the few other records concern fossil specimens from the upper Tertiary period of southeastern Europe. The raphe system (the terminal raphe fissures turning to opposite sides at both poles) of $N$. turriformis is similar with $N$. reinchardtii Grunow. In old tectonic aligomictic deep lakes Ohrid and Prespa, more than 150 new taxa were described (LEVKov et al. 2007), thus there is still a tremendous amount of work to do to uncover the phylogenetic relationships of the freshwater diatoms in Lake Fuxian.

\section{ACKNOWLEDGEMENTS}

This work was supported by the projects of National Sciences and Foundation of China (Grant No. 41672173 and 41877296) and the Yunnan Provincial government Leading Scientist Program (No. 2015HA024). We give special thanks to Dr. Enlou Zhang, and Zhijun Gong for their help in field works, and Dr. Han Wu for creating figures. 

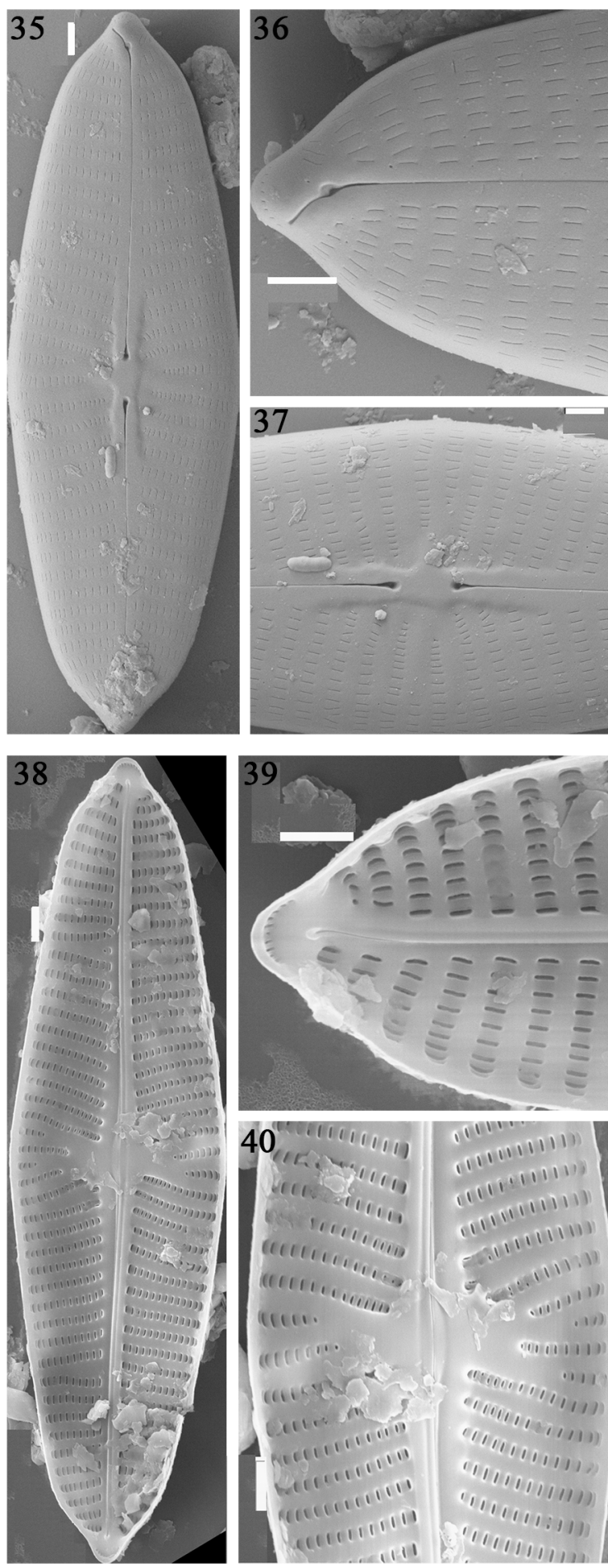

Figs 35-40. Navicula turriformis, SEM, external views: (35) entire valve view; (36) view of the ends with a clear curve to the opposite sides; (37) central portion of the valve showing large drop-like and inclined to the primary valve side; (38) internal valve view; (39) raphe terminates with distinct helictoglossa; $(40)$ central portion of the valve with scarcely expanded and inclined to the secondary valve side. Scale bar $3 \mu \mathrm{m}$.

\section{REFERENCES}

Battarbee, R.W. (1986): Diatom analysis. - In: Berglund, B.E. (ed.): Handbook of Holocene Palaeoecology and Palaeohydrology. - pp. 527-570, Wiley, Chichester.
BRoOKs, J.L. (1950): Speciation in ancient lakes. - Quarterly Review of Biology 25: 131-176.

Cui, Y.D. \& Wang, H.Z. (2005): Potamothrix scleropenis sp. nov. (Oligochaeta: Tubificidae) from Fuxian Lake, the deepest lake in southwest China. - Zoological Science 22: $1353-1357$.

EDLund, M.B. \& JAHN, R. (2001): Biogeography and endemism of diatoms: report of a workshop. - In: ECONOMOUAmILLI, A. (ed.): Proceedings of the XVIth International Diatom Symposium. - pp. 575-587, Amvrosiou Press, Athens.

Edlund, M.B. \& Soninkhishig, N. (2009): The Navicula reinhardtii species flock (Bacillariophyceae) in ancient Lake Hövsgöl, Mongolia: description of four taxa. Nova Hedwigia, Beihefte 135: 239-256.

Gong, Z.J. \& LI, Y.L. (2011): Cymbella fuxianensis Li and Gong sp. nov. Bacillariophyta) from Yunnan Plateau, China. - Nova Hedwigia 92: 551-556.

Gong, Z.J.; Metzeltin, D.; Li, Y.L. \& Edlund, M. B. (2015): Three new species of Navicula (Bacillariophyta) from lakes in Yunnan Plateau (China). - Phytotaxa 208: $135-146$.

Hustedt, F. (1934): Die Diatomeenflora von Poggenpohls Moor bei Dotlingen in Oldenburg. - Abhandlungen und Vortragen der Bremen Wissenschaftlichen Gesellschaft 8/9: 362-463.

Lange-Bertalot, H. (2001): Diatoms of Europe Vol. 2. Navicula sensu stricto, 10 Genera separated from Navicula sensu stricto, Frustulia. - 526 pp., A.R.G. Gantner Verlag K.G., Königstein, Germany.

Lange-Bertalot, H. \& Metzeltin, D. (1996): OligotrophieIndikatoren. 800 Taxa repräsentativ für drei diverse SeenTypen. - In: LANGE-BERTALOT, H. (ed.): Iconographia Diatomologica. Annotated Diatom Micrographs. Vol. 2. Ecology-Diversity-Taxonomy. - 390 pp., Koeltz Scientifc Books, Königstein, Germany.

Levkov, Z.; Krstic, S.; Metzeltin, D. \& Nakov, T. (2007): Diatoms of Lakes Prespa and Ohrid. About 500 taxa from ancient lake system. - In: LANGE-BERTALOT, H. (ed.): Iconographia Diatomologica. Annotated Diatom Micrographs. Vol. 16. Biogeography-Ecology-Taxonomy. - 417 pp., A.R.G. Gantner, Ruggell, Liechtenstein.

LI, Y.L.; Gong, Z.J.; WANG, C. \& ShEN, J. (2010a): New species and new records of diatoms from Lake Fuxian, China. - Journal of Systematics and Evolution 48: 65-72.

Li, Y.L.; Metzeltin, D. \& Gong, Z.J. (2010b): Two new species of Sellaphora (Bacillariophyta) from a deep oligotrophic Plateau lake, Lake Fuxian in the subtropical China. - Chinese Journal of Oceanology and Limnology 28: 1160-1165.

Maidana, N.I. (1996): Diatomeas fosiles nuevas o poco conocidas para la Argentina: Lago Nahuel Huapi (Brazo Campanario), Prov. de Río Negro. - Boletín de la Sociedad Argentina de Botanica 31: 177-191.

SKET, B. (2000): Fuxiana yangi g.n., sp.n. (Crustacea: Amphipoda), a "baikaloid" amphipod from the depths of Fuxian Hu, an ancient lake in the karst of Yunnan, China. - Archiv für Hydrobiologie 147: 241-255.

Skuja, H. (1937): Algae. - In Handel-Mazzetti, H. (ed.): Symbolae Sinicae, botanische Ergebnisse der expedition der Akademic der Wissenschaften in Wien nach Südwest-China 1914/1918 1. - pp. 1-106, Julius Springer, Vienna.

Wang, S. \& Dou, H. (1998): Lakes in China. - 580 pp., Science Press, Beijing. 
YANG, J.X. \& CHEN, Y.R. (1995): The Biology and Resource Utilization of the Fishes of Fuxian Lake, Yunnan. - 224 pp., Yunnan Science and Technology Press, Kunming. Zhu, H.Z. \& Chen, J.Y. (1994): Study on the diatoms of the Wuling Mountain Region. - In: SHI, Z.; WeI, Y.; Chen, J.; Li, Y.; Zhu, H.; Li, R. \& YAO, Y. (eds): Compilation of Report on Survey of Algal Resources in the Southwestern China. - pp. 79-130, Science Press, Beijing.

(C) Czech Phycological Society (2020)

Received September 3, 2019

Accepted April 6, 2020 